\title{
Nonviolence and the Framework of Jain Ethics
}

A defining feature of the Jain tradition is its emphasis on ethical behavior that emulates the twenty-four Jinas. These liberated teachers showed the path of right worldview, knowledge, and conduct needed to free oneself from repeated births in samsära. In popular presentations of the tradition, the path of conduct is frequently summarized through the five Jain vows. The first and most primary vow is ahims $\bar{a}$, or nonviolence. The term signifies the opposite of hims $\bar{a}$-violence, a derivative from the Sanskrit verbal root han-, meaning to hit, strike, or kill (MonierWilliams 1899, 1287). ${ }^{1}$ It is signified visually in the contemporary Jain symbol of an open palm raised in the abhaya-mudrā of peace and fearlessness (figure 3 ). As the first vow, nonviolence provides the basis for the other four vows: truthfulness (satya), nonstealing (asteya), sexual restraint (brahmacarya), and nonpossession (aparigraha). These vows are to be practiced fully, as great vows (mah $\bar{a}-v r a t a)$, by mendicants; and partially, as minor vows ( $a \eta \underline{u}$-vrata), by lay Jains.

These five vows might appear to be the logical starting point in our effort to examine the Jain foundations for bioethics. However, the understanding of right conduct has evolved a great deal in the Jain tradition from the earliest mendicant texts to the contemporary practices of modern lay Jains, such that the vows alone do not paint a sufficient picture. In order to understand the complex foundations of Jain conduct, and its relation to nonviolence, we will move beyond the traditional account of the vows and excavate the philosophical layers that have shaped Jain practice among mendicants and householding laypeople.

In this chapter, we examine the ethical doctrines in the earliest layers of the Jain canon, as well as emerging accommodations for mendicants and lay Jains. These accommodations include a growing emphasis on the motivations that inform actions, as well as a developing doctrine of beneficial karma and good rebirth. 


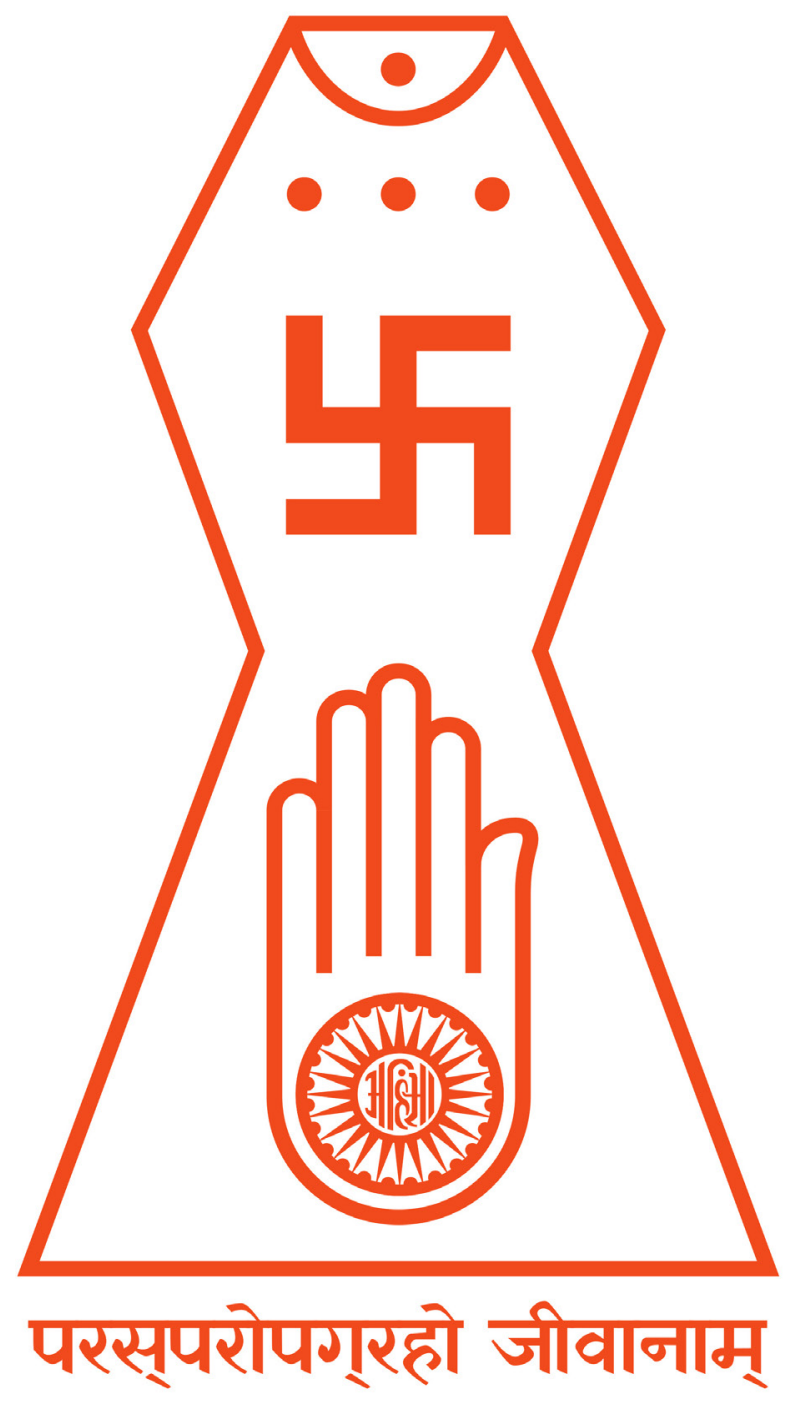

FIGURE 3. Various Jain groups adopted this hourglass-shaped cosmos as an emblem (pratika) of their tradition in 1975 in celebration of the 2,50oth anniversary of Mahāvira's attainment of liberation. It includes several other Jain symbols, from top to bottom: a liberated siddha atop the universe; the "Three Jewels" of right worldview, knowledge, and conduct; the svastika, denoting four birth states within the cycle of rebirths, as well as the community of monks, nuns, laymen, and laywomen; the symbol of ahimsā in Jainism - an open palm in the abhaya position, dispelling fear, with the word ahimsā in the devanägari script at the center. Finally, the bottom phrase parasparopagraho jīvānām describes the mutual support of living beings (TS 5.21). See also Jaini $(2001 / 1979,316)$. 
The evolving Jain understanding of ethics is reflected in a formalized framework known as the fourteen guna-sthānas, or "ladder of karmic removal." We show the logic of this ladder in relation to the five causes of karmic bondage, noting key milestones in which a particular cause of bondage is overcome, advancing one on a path of increased restraint and decreased violence. Not only must the vows be understood in the context of this ladder, but additional key Jain concepts such as compassion (anukampā), non-one-sidedness (anekānta-vāda), and carefulness (apramāda) gain clarity in light of the guna-sthāna framework of advancement or regression.

Because we are examining foundations in Jainism for bioethics, which is a discipline more in the purview of lay Jains than of mendicants, we pay special attention to texts describing layperson conduct (śrāvaka-ācāra). The texts detail violations of the vows and vices that impede karmic progress for laity, including guidelines intended to limit harms in the course of one's personal activity, family responsibility, and vocational obligations.

We conclude the chapter by summarizing three foundational Jain ethical principles that derive from the textual and philosophical analysis herein. While these principles place a central and unparalleled emphasis on nonviolence, a comprehensive view of Jain ethics exceeds a single concept. Any examination of Jainism and contemporary bioethics requires a wider grasp of several concepts within a dynamic framework of karmic progression and regression that informs the distinct ways of living, disciplines, and goals for mendicant and lay Jains.

\section{AVOIDING VIOLENCE IN THE EARLY \\ ŚVETĀMBARA CANON}

The Jain "canon" includes a large collection of texts. Most Śvetāmbara Jains accept a full or modified list of forty-five canonical texts, or Āgamas, that were codified at several different councils. ${ }^{2}$ This list of forty-five is composed of the Angas (and the no longer extant Pūrvas) that contain knowledge passed directly from a Jina to students. Later texts within this list were composed by mendicant leaders, often as practical commentaries on the early Āgamas. Digambaras, however, reject the authenticity of this collection, believing that the canonical texts were lost, and that only some contents of the canon were remembered and passed on. Consequently, the Digambara sect has a collection of texts that are primarily postcanonical expositions composed by mendicant leaders (Jaini 2001/1979, 47-87; Wiley 2009, xix-xxvi). We primarily consider Śvetāmbara canonical texts here as they provide a unique window into the development of the early Jain ethical doctrines.

\section{Parigraha and Ārambha}

The first parts (śruta-skandha) of the Ācāränga-sūtra and Sūtrakrtāinga-sūtra (Ācārānga-sūtra I and Sūtrakṛtāinga-sūtra I, respectively), which are considered to 
represent some of the earliest surviving portions of the Śvetāmbara canon, ${ }^{3}$ place absolute primacy on renouncing harmful activities through the mendicant way of life. In his book Early Jainism, K.K. Dixit notes that although the five great vows appear jointly in the Sütrakrtānga-sūtra I, their treatment is "almost perfunctory," and they are not mentioned together in the Ācārānga-sūtra I (1978, 7; see also Ohira 1994, 8-9). ${ }^{4}$ A greater emphasis is placed, in these early canonical strata, on possession (parigraha) as one of the worst vices for an ascetic who has renounced the world. Possession is linked with violence $(\bar{a} r a m b h a)^{5}$ to form a pair of the two main kinds of harmful activities that sustain one's entrapment in the cycle of rebirths (Dixit 1978, 5; Ohira 1994, 8).

Dixit explains that in the early portions of the canon possession, or parigraha, primarily refers to attachments to material objects and familial/social relations (Dixit 1978, 5, 19). ${ }^{6}$ Due to the pursuit of enjoyment or necessities for oneself or others, these attachments lead to violence, or ārambha, toward living beings. As described in chapter 2, living beings range from beings in water and fire (etc.) to plants, animals, and humans. ${ }^{7}$ Dixit describes the intractable relationship between attachment and violence this way: "[A]ll attitude of parigraha towards one must involve-directly or otherwise - an attitude of ärambha towards another," meaning that every accumulation of a material good or pleasure enacts a harm on a living being (5). In this dynamic, notes Dixit, ārambha functions as an immediate cause of a harmful activity and parigraha as its proximate cause (5).

The term a rambha is derived from the verbal root rabh-, with the prefix $\bar{a}$-, meaning to undertake, commence, or begin (Monier-Williams 1899, 150). ${ }^{8}$ William Johnson explains that the term evolved a sense of physical violence or killing, perhaps through the Jain account of a cosmos permeated with living beings, in which "beginning," "commencing," or "undertaking" any action would inevitably cause harm to some living being. Hence, he states, the two meanings of the termto undertake an action and to kill-were probably understood to be synonymous (1995a, 38-39). Suzuko Ohira points out that in such a view of the world, one could not escape committing violence: "In breathing, speaking or stretching out his [sic] hand, he cannot but kill wind-beings. In extinguishing fire he murders firebeings, in walking a street he harms earth-beings, and in shaking a water pot he hurts water-beings" $(1994,5)$. In line with this, any action would result in accruing karma and one's continued entrapment in the suffering cycle of rebirths, ${ }^{9}$ though the precise mechanisms for how karmic bondage occurs were not yet formalized (Dixit 1978, 9). ${ }^{10}$ Therefore, the only way to liberation was considered to be, at least theoretically, nonaction (akarman) by which one could lead a life of nonviolence (anārambha) $(1994,6,10)$.

Already in these early portions of the canon, action-often in relation to causing some kind of harm-is understood to be threefold: (1) one can perform it directly, (2) cause another to perform it, or (3) approve of another performing it. As stated succinctly in the first teaching of the Ācārāinga-sütra, the three types of 
actions are "I did it," "I caused another to do it," and "I shall approve of ${ }^{11}$ another doing it" (ĀS 1.1.1.5). ${ }^{12}$ All three are understood as resulting in karmic retribution. The earliest canonical strata also hardly distinguish between deliberate and nondeliberate actions. The Ācārānga-sūtra 1.5.4.3, for example, describes a monk who harms living beings, even though virtuous and observant in conduct. It states that the result of such action will come to fruition in the present lifetime. On the other hand, if harm occurs that is due to not observing the rules, the text states that a monk needs to perform an atonement (viveka). ${ }^{13}$ While there is an acknowledgment of a difference between the two actions, they are both understood as generating karmic cost. One of the main ways that mendicants are instructed to circumvent both attachments and violent activity in any of the three ways is by avoiding the preparation of their own food or the purchase of any needed goods. Rather, these items must be collected as alms from householders, ideally, without forming any attachment to what is collected or to householders themselves, who are described quite negatively in the Ācārāinga-sūtra I as careless, greedy, and violent, among their many other undesirable traits. A mendicant should, further, lead a wandering rather than a sedentary life.

\section{Solitary Mendicancy, the Goal of Liberation, and Violent Householders}

It is not entirely clear what the state of the mendicant community was at the time that the Ācāränga-sūtra I reflects. Several sections of the text mention students being taught by teachers, but the text also asserts that those who have realized the truth do not need a teacher at all and may live as solitary mendicants. This possibly indicates that mendicants either lived in small groups comprising a teacher with junior mendicants as students, or-in the case of highly developed wandering mendicants-led a solitary life (A $\bar{S}$ 1.6.2.3), with the student period likely functioning as a preparatory stage for the latter. Solitary life and a stringent emphasis on nonaction are certainly highlighted as an ideal lifestyle, promoting a mendicant path that emulates the asceticism and self-reliance of Mahāvīra and other Jinas. Drawing on the Ācārānga-sūtra 1.8, Ohira describes Mahāvīra’s arduous asceticism in the following way:

He went alone stark naked, without using cold water, not bathing, not cleaning his teeth, not using fire and not scratching his body. He slept little, was always vigilant, and wandered around carefully without speaking much. He bore all the hardships ..., ate coarse food and often fasted. He exposed himself to the heat and sat squatting in the sun. He often practised meditation.... He might have eaten only once a day, because food, necessarily obtained by killing living beings, should be cut down in frequency, quantity and quality. Likewise using medicine which is acquired by grinding herbs, roots, etc., of living beings would have been avoided by him. He had a mission to spread his message and train his disciples, but otherwise he would probably have refrained from unnecessary speech, for speaking involves violence to subtle beings. $(1994,10)$ 
Ācārānga-sūtra I speaks, further, of liberation as an immediately attainable goal for one who adopts the correct practices, and sharply contrasts liberation as the only worthwhile aim with every other possible outcome. These portions of the canon do not speak of a good rebirth; on the contrary, any path that does not lead to liberation is a wrong path that should be avoided (ĀS 1.2.3). This means that there is no consideration of a good householder life, since the stringent understanding of violence to living beings as a result of attachments functionally excludes laity from the possibility of liberation. Laypeople, who by definition participate in social and family life, are viewed as intrinsically attached to the activities of doing, causing, and approving of harm. Unsurprisingly, then, the behavior of householding lay Jains is described as a direct contradiction to the mendicant ideal (Dundas 2002, 42).

The question arises: if the Jain ethic of nonviolence is only for mendicants, ideally removed from society, and laypeople are innately unable to practice it, how can we examine any Jain foundations for bioethics, a discipline shaped by social and institutional activities? To answer this, we have to note that the early textual references that we are studying tend to represent ideal types of practitioners. However, even these texts are nuanced and record deviances from the arduous ideals, as evident in the next section. Furthermore, various shifts in the understanding of the doctrine and goals of practice seem to have occurred early on that enabled the development of Jainism as a fourfold community of monks, nuns, laymen, and laywomen with two distinct but related paths toward nonviolence and purification.

\section{EMERGING ACCOMMODATIONS \\ FOR MENDICANTS AND LAITY}

As is becoming clear, the content of the Jain canon is not uniform. Rather, texts record important shifts among an evolving religious tradition. This includes accommodations for mendicants who are less disciplined, as well as for laypeople.

\section{Failure on the Path and Bad Reputation}

While the Ācārānga-sūtra I emphasizes the ideal of the solitary ascetic life, it indicates that some mendicants, despite understanding the nature of samsāra and their own bondage within it, are not able to follow the path to the same extent as others. Some of these "weaker" individuals may give up the mendicant life, it states, and in so doing gain a bad reputation (ĀS 1.6.4.3). While householders are generally shunned, as noted above, this statement seems to indicate a concern with how mendicants are perceived, possibly by the broader, householding community. The Sütrakrtāinga-sütra I, similarly, upholds the ideal of mendicants that lead solitary lives, but also records the difficulty of the ascetic path and failure upon it. The text identifies mendicants, for instance, who may be too weak to handle difficult austerities and return to their homes, like elephants who have been broken down with 
arrows (SKS 1.3.1.17). Further, it reprimands students for all sorts of unsuitable behavior toward their teachers and urges them to obey and serve the teachers (SKS 1.9.33), with one teaching even stating that only one who lives with their teacher will reach the end in liberation (SKS 1.14.4). The Uttarädhyayana-sütra, a later text from the early portion of the canon, also celebrates the solitary mendicant (US $2.18,15.16$ ), yet describes one who does not serve and stay with the teacher as a bad mendicant (US 11.14, 17.5, 17.17) (Dixit 1978, 23-25).

These references could be interpreted as reflecting a gradual establishment of more stable groups of mendicants beyond the smaller groups of students living with their teachers during their education mentioned above, ${ }^{14}$ or even the existence of several possible modes of mendicancy. Paul Dundas suggests the possibility of a coexistence of two alternative mendicant lifestyles already in the early phases of the development of the Jain community:

The early medieval scriptural commentaries and texts on monastic law ... bifurcate
Jain monastic life into two modes ( kalpa), namely the jinakalpa, the solitary and
highly ascetic way of life corresponding to that of the Jinas in which indifference to-
wards oneself and others is cultivated, and the sthavirakalpa, "the way of the elders"
which was followed by those monks living in groups. This is arguably similar to the
model which some scholars have identified as existing in the early śramana tradition
when at the outset there was the simultaneous possibility of two types, complemen-
tary as much as contrasting, of renunciatory life, one being more radically isolation-
ist in style and located in the "forest", the other more communal in orientation and
connected with town and village. $(1997,498$; cf. Dixit 1978,28$)$

\section{Good Rebirth and Nonviolent Householders}

The Sütrakritainga-sūtra I also records the emergence of the possibility of a good rebirth. It states: "Having heard the doctrine, which was proclaimed and established by the Arhat [i.e., Mahāvīra], and which is supported with arguments, believers will either come to an end of their [worldly] life or become like Indra, king of the gods" (SKS 1.6.29). While the Ācāränga-sūtra I sees only liberation as a worthy result of religious practice, the Sütrakrtānga-sūtra I contends that the path outlined by Mahāvīra will lead to either liberation or the other good option of being reborn in the heavenly realm while staying in samsāra. ${ }^{15}$ In line with this expanded goal of the religious path, the Sütrakritànga-sūtra I explains that a nonviolent householder will be reborn in the heavenly realm (SKS 1.2.3.13).

The above-mentioned concern about the reputation of mendicants-as well as such an early inclusion of laity in the spiritual path-suggests that mendicants and laity were most likely more intertwined than some passages from these early canonical strata might lead us to infer. Dundas notes that the Buddhist texts that discuss the early Jain community would most likely have mentioned that Jain mendicants were not associated with laypeople if this were the case $(1997,504)$. Without them, he asks, "how . . . could such a community adequately reproduce itself? How did a corpus of teaching come to be organised and expanded?" (496). 
While later texts in the early canon continue to focus on mendicants rather than laity, the possibility of a good rebirth for virtuous householders remains. For example, the Uttarädhyayana-sütra ${ }^{16}$ differentiates between the "death of the unwise," who is violent and attached to pleasures, and the "death of the wise," who is nonviolent and controls the senses (see chapter 7). The text states that both virtuous mendicants and householders fall under the second category, with the latter being reborn as heavenly beings and the former attaining either liberation or rebirth in the heavenly realm (US 5.24-25). Dixit points out that this is a "position maintained by all later Jaina authors" $(1978,22)$. This section of the Uttarädhyayana-sütra also points out that there are even householders who are more advanced in self-control than some mendicants (US 5.20).

As indicated above, the possibility of meritorious karma is not a feature of the earliest canonical strata. Karma - as a factor responsible for binding living beings in samsāra-is considered to be a result of any action, and has an inherently negative quality. Mendicant restraints can stop the karmic accrual but cannot positively influence it. By the early common era, however, the Jain doctrine accepted that liberation was no longer attainable in our part of the cosmos, owing to the weakened presence and strength of Mahāvīra's teaching in the centuries after his death. ${ }^{17}$ With that change, practice was no longer focused only on annihilating karma, but also on gaining beneficial karma through meritorious actions that could lead to a good rebirth. Dundas highlights the significance of the notion of meritorious and nonmeritorious actions as providing "an ethical dimension which was meaningful not just for ascetics but for a community which as a whole also contained lay people" (2002, 96-97).

As the mendicant community grew, it became increasingly dependent on its lay supporters (Dundas 2002, 187). One way this is reflected in the texts is in detailed rules for mendicants' interactions with laity. The Ācārānga-sūtra II, for instance, enumerates many regulations guiding mendicants in their encounters with laypeople and, in effect, "training" laity how to properly provide for mendicants' basic needs within very circumscribed limits. In order to maintain strong lay support, mechanisms of mutual benefit evolved. The Sütrakrtānga-sūtra, for example, references a minimal exchange between laity providing food and mendicants providing teaching (SKS 1.7.24-27). Beyond serving practical purposes, the value of this arrangement was expanded to include karmic benefit such that a layperson's disciplined effort to feed a mendicant and the mendicant's proper reception of food, both according to detailed rules meant to minimize harms, could earn them karmic merit (DVS 5.1.100; see also Johnson 1995a, 30-31).

\section{Activities, Motivations, and Karmic Retribution}

The notion of collectively assuming the five great vows, together with the sixth vow of refraining from eating at night, seems to have been developed by the time of the Daśavaikālika-sūtra ${ }^{18}$ (Dixit 1978, 28-29; Ohira 1994, 9). In the text, as Ohira points out, the vows are explained in the form of the so-called trividham trividhena 
formula $(1994,9)$. This represents the threefold notion of action (karana) explained above, along with the notion that activities (yoga) can be performed with the body, speech, and mind. ${ }^{19}$ In line with this, the observance of the first great vow is, for example, explained as refraining from violence by not performing a violent act oneself, not causing somebody else to do it, and not approving of somebody else's violence, all three either with the body, speech, or mind (DVS 4.11). This triple formulation-or what Dixit calls "a triple evil act committed in a triple manner" $(1978,89)$-becomes standard in later canonical texts (Ohira 1994, 154). Ohira points out that between the third and first centuries BCE the term yoga came to encompass all actions committed by living beings, replacing the earlier karman as the term for action in general. ${ }^{20}$ Karman gradually developed into a specific technical term signifying karmic matter $(1992,7-8,19,141,175)$.

Johnson suggests that in the formulation of the three different methods of violence-doing, causing, or allowing/approving of-the last term may have evolved from a prohibition of physically allowing harm in the earliest canon, to a prohibition of mentally approving of harm in the later canon. He argues that initially at least some Jains may have understood the third element- "to fully permit, or allow or consent to, wholly acquiesce in, or approve of" (Skt. samanujānīyāt) as "one should not allow others to commit violence if one is aware of their action" (1995a, 9; emphasis added). ${ }^{21}$ The physical character of intervention, Johnson argues, eventually diminished as the canon gradually "internalised the idea to a matter of [mental] attitude, of approval or disapproval” (1995a, 9; emphasis added).

The early canonical strata do not seem to give much weight to the motivations behind activities when it comes to karmic retribution. As indicated above, the Ácäränga-sütra I is uncompromising in its understanding that every action draws karma. The Sütrakṛtāinga-sūtra I, further, attributes the distinction between mental intent and physical action to the wrong view of the kriyāvādins. This view distinguishes between (a) intentional violent action that is carried out, (b) nonintentional violent action that is carried out, and (c) mere violent intention. The first, according to this wrong view, accrues the most karma. The text states: "One who intends [to harm a living being] but does not do it by [an act of] the body, and one who harms it unknowingly, both are affected through a contact [with the act], but the demerit [in their case] is not very developed" (SKS 1.1.2.25). To put it another way, this passage suggests a twofold significance of mental action: first, that the mental willingness to harm, even when not accompanied by physical action, still accrues modest karma; second, physical harm that is not accompanied by mental action, also accrues modest karma. The first assertion seems to expand karmic accrual to encapsulate mental formations; the second assertion seems to provide a way to diminish karmic accrual if physical actions that cause harm lack mental intention. The text clearly positions itself against such a view.

Accordingly, the Sütrakrtānga-sūtra II mocks Buddhists for emphasizing the importance of intention. In line with their thinking, the text claims, someone who 
pushes a spit through a gourd, mistakenly thinking that it is an infant, is a murderer. On the other hand, a person who intends to roast a gourd but accidentally roasts an infant is not considered a murderer (SKS 2.6.26-28). The idea that the absence of intention to harm could in any way karmically redeem the action that results in harm is vehemently rejected. Nevertheless, the differentiation between deliberate and nondeliberate actions with regard to karmic accrual gradually took hold in the Jain teachings, and increasingly more emphasis was placed on motivations behind actions.

The Daśavaikālika-sūtra seems to be the text to start using the umbrella term kașāya to jointly refer to the four passions of anger, pride, deceitfulness, and greed mentioned in chapter 2, which, according to Dixit, suggests a relatively late date of the text (1978, 28-29; Ohira 1994, 8). While the term kașāya does not feature in the earliest portions of the canon, all the components that this term eventually comes to represent do. Apart from attachment (parigraha) as the main cause of violence, attraction (rāga), aversion (dveșa), anger (krodha), pride (māna), deceitfulness (māy $\bar{a})$, and greed (lobha) are also mentioned as causes of violence (ārambha) in the Ācārāinga-sūtra I and the Sütrakṛtāinga-sūtra I (Ohira 1994, 8). Another cause of violence and karma that is listed in the early canon is carelessness (pramāda) (SKS 1.8.3). These terms were important in developments related to foregrounding the significance of motivations behind actions. The Bhagavatisūtra/Vyākhyāprajñapti-sūtra (Pkt. Bhagavaī-sutta/Viyāhapaṇnatti-sutta) ${ }^{22}$ states that a disciplined mendicant who observes his duties carefully, performs his actions in line with religious duties (îryappatha-kriyā), because his passions have been extinguished and he acts in accordance with the vows ( $\mathrm{BhS} 7.7 \$ 309 \mathrm{~b}$ ). While such actions still accrue karmic cost, they attract only short-term karma (BhS $3.3 \$ 182 b)$.

[A] disciplined monk who performs ìryāpatha kriyā binds karma at the first moment, experiences it at the second moment and purges it at the third moment, inasmuch as a bundle of hay burns as soon as it is thrown into fire, drops of water on red hot iron dry up instantly, and a boat with a hundred holes can float when the holes are closed. (Ohira 1992, 145)

This holds, for example, even if a monk accidentally kills a living being while walking carefully (BhS $18.8 \$ 754$ b). The Bhagavatī-sütra also describes the opposite kind of behavior, which is not in line with the vows (sāmparāyika-kriȳa) (BhS 7.7\$309b). This is understood as careless conduct because of passions and not observing the vows. It attracts long-term karma. The distinction between actions that accrue short-term and long-term karma serves to differentiate mendicants who are very disciplined from those who are lax in belief and practice.

All the different shifts in conceptual frameworks and practical goals that we have discussed in this chapter so far opened the way for various efforts to systematize a path of karmic progression and regression for both mendicants and laity. 


\section{A PATH OF KARMIC REMOVAL: THE FOURTEEN GUNA-STHĀNAS}

The guna-sthānas, or "stages of qualities/virtues," is a term for a formal ladder of spiritual purification that constitutes the Jain path toward liberation. It consists of fourteen stages, or rungs, in which a jīva "exhibits different virtues (guna), indicative of increasing independence from karmic bondage" (Cort 2001a, 25). Jérôme Petit identifies several Śvetāmbara and Digambara texts that describe these steps of progress, noting that the first complete list of fourteen stages is found in the Digambara Satkhanda-ägama (c. third century CE) though with few details $(2015,110)$. Nemicandra's Gommatasāra ${ }^{23}$ likely offers the first full formalization of the framework (110-11), and, as John Cort points out, "the text through which most contemporary ideologues study and understand the gunasthānas is the second chapter of Devendrasūri's Karmagrantha" (2001a, 214, fn. 24).

The path of every being in our part of the Jain universe is karmically located somewhere upon this ladder, including the whole of humanity, both Jain and non-Jain, mendicant and laity. In theory, this means that every individual jivva can progress on parts of the ladder to some degree. However, only humans who assume the five great mendicant vows may pursue the higher rungs. It is important to note that the guna-sthannas do not represent only a path of progression. Regression is likewise possible. Helmuth von Glasenapp notes that the order of the fourteen rungs is logical rather than chronological, and that the actual path can vary from one living being to another. "This becomes still more comprehensible," he states, "if we call to mind the fact that in the morning one can be on a high level, sink down from it at noon, and climb up to it again in the evening" $(1942 / 1915,69)$. The ladder thus represents a formal succession of stages that need to be passed if one is to attain liberation. Within this fourteen-stage framework, there is a second, smaller ladder-known as the pratimās-specific to laypeople. We will address both ladders in detail in the following sections. The two ladders locate nonviolence, and the rest of the vows, within a larger framework of Jain social relations and soteriological action (Kirde 2011, 85-86), illuminating many of the ethical terms discussed above.

\section{The Causes of Karmic Bondage in the Guna-sthānas}

As already stated, Jain doctrine gradually came to consider passions, careless conduct, and conduct not aligned with the vows as affecting the nature of karmic bondage whenever bodily, verbal, and mental activities in any of the three ways are performed. Efforts to systematize the diverse threads from earlier sources eventually incorporated these factors into a scheme of five primary causes (müla-hetu) of karmic bondage (bandha): (1) wrong worldview (mithyā-darśana); (2) nonrestraint (avirati); (3) carelessness (pramāda); ${ }^{24}$ (4) passions (kașāya); and (5) the activities (yoga) of the body, speech, and mind (TS 8.1). These causes of bondage are each responsible for binding specific kinds of karma. ${ }^{25}$ 
The overcoming of the five primary causes of bondage marks key points of progress along the ladder of karmic removal. As we show below, the first cause of bondage (wrong worldview) is overcome at rung 4; the second cause (nonrestraint) is overcome partially at rung 5 when a layperson takes the minor vows, and fully at rung 6 when a mendicant takes the great vows; the third cause (carelessness) is overcome at rung 7; the fourth cause (passions) is gradually eroded in rungs 4 through 11 and completely overcome at rung 12; and the fifth cause (activities of body, speech, and mind) is overcome at rung 14 .

\section{Rungs 1-4: From Wrong Worldview to Right Worldview}

The first major move along the ladder is getting from the first to the fourth rung, from wrong worldview (mithyā-darśana, mithyā-drșți, mithyātva) to right worldview (samyag-darśana, samyag-dṛstiti, samyaktva). Banārsīdās describes the shift to the fourth rung as moving from "deluded" (mü $h h a)$ self to "clear-sighted" (vicakșana) self (AA 1-4, trans. Petit), and in line with this, Nathmal Tatia compares it to a person who was born blind gaining sight, an experience accompanied with joy $(1951,273)$. Because right worldview is the necessary condition to achieve right knowledge and right conduct (see the "Three Jewels" in chapter 2), its importance cannot be overstated. As Jaini puts it, "the significance of samyak-darśana in the life of the soul is second only to that of attaining Jinahood itself" (2001/1979, 144). Its attainment is neither an easy nor a linear task.

At the first rung of wrong worldview, all five causes of karmic bondage operate. Glasenapp lists specific activities that attract worldview-deluding karmas (darśana-mohaniya-karman), resulting in a fundamentally mistaken worldview: "The teaching of a false [teacher], the hindrance of the true religion, the blasphemy of the Jains, of the saints, of the images of gods, of the community, of the canon, the rape of sacred objects" $(1942 / 1915,63)$. The delusion (moha) that is characteristic of this stage and consists of inadequate knowledge of the "reals" or the fundamental categories of existence (tattva), including the nature of karmic bondage, karmic removal, and liberation (GJK 15-18; see chapter 2), means that all jivas-from one-sensed beings to humans-"who either have never heard the Jain teachings or else have consciously rejected them" reside here (Cort 2001a, 26).

The capacity to take the initial step of leaving this state rests in the jiv $a$ 's innate qualities that can never be fully subsumed by karma (see chapter 2). According to Jaini, the jiva "possesses a sort of built-in advantage, an everpresent tendency to develop its qualities and temporarily reduce the influence of the karmas" $(2001 / 1979,141)$. From this arises a universal urge toward self-development, present even in the smallest life-forms, to combat the passions and deluding karmas that prevent it (143), often-but not exclusively-in combination with various external factors that encourage this development (Tatia 1951, 268). The initial confrontation with one's bondage (yathā-pravrtta-karana ${ }^{26}$ may be followed by two other processes, apürva-karana and anivrtti-karana. Through these, respectively, (1) the 
duration and intensity of all karmas that are bound are reduced (continuing the process started during the yathā-pravrtta-karana) and (2) the worldview-deluding karmas are temporarily suppressed, enabling a brief experience of right worldview at the fourth rung (Jaini 2001/1979, 144, cf. 146; Tatia 1951, 269-73).

Jaini describes this brief glimpse as a "first awakening" of right worldview at the fourth rung, before-as is most common-the suppressed karmas assert themselves again and the jiva falls back to the third and possibly second rung, ${ }^{27}$ from where it returns to the beginning of the ladder $(2001 / 1979,134,145)$. But the glimpse is transformative as it eradicates a great amount of already bound karmas, weakens other karmas, as indicated above, as well as limits future influx of karmas, thus generating longer durations of right worldview. Jaini states that a jiva that retains right worldview at death will not be reborn as a hell-being or any of the lower life-forms of the tiryañc birth state (see chapter 2), and its path to total karmic removal, while still of an immense duration, will be considerably shortened, with liberation guaranteed (144-45).

The fourth rung of right worldview is considered the first official step toward liberation. Glasenapp writes that this stage belongs to those "who believe renunciation worthy of being striven after" $(1942 / 1915,79)$. According to Jaini, "it is said that only one who has undergone such an experience [in the fourth stage] should be called 'Jaina,' for only he [sic] has truly entered upon the path that the Jinas have followed" (2001/1979, 146). Both five-sensed humans and five-sensed animals with a mind can reach this stage (SSi 2.3\$258; Glasenapp 1942/1915, 70; Wiley 2006b, 252). Since right worldview is the prerequisite step for greater advancement along the ladder, it is important to note that many beings in the universe who have not reached the fourth rung are not actually considered to be on the path toward liberation at all. Likewise, one who falls below the fourth stage, in effect, slips off the path, and must again strive to regain right worldview.

While a living being may lapse back many times to lower stages after reaching the fourth rung, the permanent attainment of the right worldview signifies a complete overcoming of the first cause of bondage, that of wrong worldview (mithya-darśana). All of the worldview-deluding karmas as well as the gross forms of passions-called "pursuers from the limitless past," or ananta-anubandhī passions, which express themselves in extreme kinds of attachment and aversion-are conquered on this occasion (Jaini 2001/1979, 118-19). A living being that attains it will never again regress below the fourth rung and will reach liberation in no more than four lives (146).

In spite of attaining right worldview, however, a jivva at this stage still lacks right conduct. As Tatia states, "It has the requisite vision and knowledge and wisdom. It has the right will. But the energy for self-control is wanting" (1951, 277; see also Glasenapp 1942/1915, 79). While overcoming deluding karmas and gross passions enables the possibility for right conduct in later stages, nonrestrained actions and associated passions still characterize this rung. 
Changing Attitudes and Behavior: The Development of Compassion. Glimpsing the fourth stage, even momentarily, transforms individuals who have had this experience, and Jains maintain that the results of this change are not only internal (bhāva-samyaktva), but are evident also externally (dravya-samyaktva). Jaini details a foundational realignment of consciousness regarding the attitude toward oneself, from being a "self" that identifies with external factors, objects, and results (e.g., body, wealth) and aims to actively intervene in the world, to gaining a focus on the internal self. This reorientation results in a state of bliss (sukha), "hardly imaginable to an ordinary person," and tranquility (praśama), as well as fear of and disillusionment with the worldly existence (samvega), sometimes leading to renunciation (2001/1979, 147-49; see also YŚ 2.15; Brekke 2005, 75-75; Williams 1963, 42). The experience of right worldview produces confidence (āstikya) in the Jain teachings, particularly the "reals," preventing skepticism, nihilism, and the dogmatism of non-one-sided views. A clear understanding of the true relation between eternal substances (dravya) and their constantly changing modes (paryāya) (see chapter 2), further, "generates a feeling of great compassion (anukampā) for others"(Jaini 2001/1979, 150). We address this important ethical concept briefly here. ${ }^{28}$

The role of compassion (anukampā, dayā, kärunya), its precise meaning, and its relation to nonviolence and karmic bondage in Jain ethics are not always clear. In the early Śvetāmbara canon, for example, one of the motivations for not pursuing violence (ārambha) seems to be a recognition that all beings are universally vulnerable to pain, akin to oneself. In those same early texts, however, attachments (parigraha) to social relationships are also a cause of violence and subsequent karmic bondage (see chapter 2). If the ultimate goal is to avoid attachment and escape from the world of suffering, does that mean that orthodox mendicant practice is incompatible with a thoroughgoing sense of and/or acting from compassion?

Jaini states that the experience of right worldview provides an insight into the nature of bondage and through it a deep awareness of and a sense of identity with all the other living beings trapped in the cycle of rebirths (2001/1979, 149-50), much like the awareness of the universal experience of pain mentioned above. However, he also notes that compassion gained in right worldview signifies something different than its typical social meaning: "Whereas the compassion felt by an ordinary [hu]man is tinged with pity or with attachment to its object, anukampa [compassion] is free of such negative aspects; it develops purely from wisdom, from seeing the substance (dravya) that underlies visible modes [paryāya], and it fills the individual with an unselfish desire to help other souls towards mokșa" (150). ${ }^{29}$ A moderate experience of compassion at the fourth rung, Jaini says, "brings an end to exploitative and destructive behavior, for even the lowest animal is now seen as intrinsically worthwhile and thus inviolable" (150). On the other hand, a strong desire to help others who are suffering in the cycle of rebirths may accumulate the auspicious karmas that produce the birth of a Jina (150; see 
also Wiley 2006, 447). The fundamental assertion articulated in the Tattvārthasütra that "[the function] of living beings is to support (upagraha) one another" (TS 5.21) highlights the importance of such help. The Tattvārthädhigama-bhāsya understands this support as offering advice: "The support of jivas is advice to one another with regard to that which is beneficial and that which is unbeneficial (hitaahita-upadeśa)" (TBh 5.21), which Siddhasenaganin glosses as helping others in attaining that which is beneficial (hita-pratipädana) and preventing that which is unbeneficial (ahita-pratiședha) (TT 5.21).

The relationship between attachment and compassion in relation to the different stages of the ladder of karmic removal, including those beyond the fourth rung, is addressed in various postcanonical texts. Wiley notes that Digambara commentaries to the Tattvārtha-sütra distinguish between two kinds of right worldview: (1) right worldview with attachments (saräga-samyag-darśana) and (2) right worldview without attachments (vìtaräga-samyag-darśana). The external characteristics (including compassion) of a person who has experienced the fourth rung, which were listed above, fall under the right worldview with attachments. The right worldview without attachments, on the other hand, "is characterized only by the purity of the soul itself (ätma-viśuddhi-mātra)" (2006a, 440; see also PS 2.65-67). According to these texts, compassion arises in association with the right worldview when individuals are still influenced by conduct-deluding karma that produces passions in the form of attachment or aversion (see chapter 2). It is maintained through the twelfth rung-described shortly-and relinquished with all other attachments thereafter (Wiley 2006a, 441).

In line with this, the Tattvārtha-sütra describes compassion (anukampā) as a cause that binds sātā-vedanìy-karman, a non-destructive type of karma that gives rise to pleasant feelings (see chapter 2), thus perpetuating one's entrapment in samsāra (TS ${ }^{\hat{S}} 6.13 ;^{30}$ Wiley 2006a, 439, 441-42). The Tattvārtha-sūtra, further, lists compassion (kārunya) as one of the contemplations (bhāvanā), that is, supporting practices that strengthen the vows: "Friendliness (maitrī) toward all living beings (sattva), delight (pramoda) with those whose qualities are superior (gunaadhika), compassion (kārunya) for the afflicted (kliśyamāna), and equanimity (mädhyastha) toward the ill-behaved (avinaya) [should be contemplated]" (TS ${ }^{\text {sv }}$ $7.6 ;^{31}$ trans. Wiley 2006a, 443). Compassion, then, seems to be a factor that can aid progress on the path to liberation, but since it still produces karma, it must eventually be transcended at the highest levels of the spiritual path.

How have such complex teachings on compassion been reflected in the understanding and practices of the Jain communities? In her research on Jains in diaspora, Anne Vallely argues that young, second-generation lay Jains frequently interpret compassion, not only as recognition of shared vulnerability, but also as a positive injunction to protect living beings, though she recognizes that this interpretation conflicts with the orthodox goal of overcoming all attachments (2002b, 205-13). While certain scholars see the outreach of diaspora Jains as a 
"neo-orthodox" revision of earlier restraints (Banks 1991, 244-57), there are certainly sectarian examples of active compassion among lay Jains. The Sthānakavāsi sect of Śvetāmbara Jains, for instance, distinguishes itself by venerating mendicants and encouraging merit-making activities of householders, which include not only gifting (dāna) mendicants with proper donations, but also compassionate service toward humans and animals (Wiley 2009, 203-4). Sthānakavāsī monk Ācārya Suśîlkumār (1926-94) exemplified modern social outreach by traveling in 1975 by plane - a form of travel generally forbidden to mendicants- to the United States, where in 1983 he developed a religious center called Siddhācalam for US Jains and non-Jains (Dundas 2002, 254). He actively worked to bring peace in the Punjab region of India during the 1980s, and promoted dialogue between Hindu and Muslim parties during the Ayodhya dispute in 1992. ${ }^{32}$

The Terāpanthī sect of Śvetāmbara Jains, on the other hand, originally strictly distinguished between worldly compassion (laukika-day $\bar{a}$ ) in the form of social activism and merit-making acts, and spiritual compassion (dharma-daya $\overline{\text { ) in the }}$ form of religious instruction. They viewed only the latter as part of the path to liberation (Wiley 2006a, 445-47). However, that changed in the 2oth century, particularly with Ācārya Tulsī (1914-97), the ninth leader of the Terāpanthī sect, who promoted civic engagement through the Anuvrat Movement for laity, which he established in 1949. In 1980, he also initiated an intermediary class of Jain mendicants known as saman (male) and samanī (female), who have greater flexibility with their vows and can use mechanized transport, travel abroad, and handle money in order to support Jains living in diaspora countries (Wiley 2009, 217; see chapter 5).

If anything can be deduced here regarding the role of compassion in relation to nonviolence and a Jain approach to bioethics, it is that the Jain concept of compassion indicates a comprehension of shared vulnerability and suffering, and not merely a sense of impassioned sympathy (Vallely 2018). Even if compassion is an attachment that must be ultimately overcome, as most scholars and texts seem to suggest, its experience can be a catalyst for advancement up to that point, and perhaps nurture qualities of Jinahood at an early stage.

\section{Rung 5: Lay Restraints: The Pratimās and the Minor Vows}

Having overcome the first cause of bondage of wrong worldview in the previous stage, one becomes an "active member" of the Jain community in the fifth guna-sthāna (Petit 2015, 99). This rung is called "partial restraint" (deśa-virata), since the second cause of bondage - that of nonrestraint (avirati) - is partially overcome. It results from the elimination of the apratyākhyāna-āvarana passions, or "obstructors of partial renunciation," and represents Jain laity accepting limited restraints. Tatia defines the attainment of the rung as a shift to "right vision with capacity for partial abstinence" $(1951,277)$, while Glasenapp describes it as "partial self-control" $(1942 / 1915,81)$. 
As with the previous stage, one can experience the fifth guna-sthāna for a brief or lengthy duration, and with greater or lesser intensity. In order to experience the stage fully, a layperson can undertake a series of eleven steps, called pratimās, ${ }^{33}$ which function as a smaller ladder for laity within the larger ladder of the guna-sthānas. These steps are intended to help laypeople progress from the fifth to the sixth guna-sthāna, and they accordingly provide them with religious commitments that increasingly resemble those of mendicants. Once a layperson accepts a specific pratima $\bar{a}$, the commitment is considered to be lifelong. Although Śvetāmbara and Digambara sources have some variation in the order, names, and content of the eleven steps (GJK 477; SSN 13.56-58; ŚA 4; Kirde 2011, 11; Williams 1963; 173-74), all sources affirm that the pratima ladder involves laity taking the vows. They are taken partially, as minor vows (anu-vratas), under the guidance of a teacher. ${ }^{34}$ It is important to understand where these minor vows fit into this stage more broadly.

Pratimā 1: Accepting Fundamentals. The first step in the pratimā path, called darśana-pratima, or "the stage of right views," comprises acts of devotion and preparatory restraints demonstrating the right worldview gained in the fourth stage and the commitment to Jain "fundamentals" (Jaini 2001/1979, 161). The acts of devotion express the acceptance of the Jinas as objects of worship, the Ägamas as sacred texts, and Jain mendicants as the sole proper teachers (162). One of the central devotional practices is the recitation of the foundational Prākrit mantra, called the pañca-namaskära-mantra, which pays homage to the five supreme beings (pañca-parameșthin): (1) the Jinas (arhat), (2) the liberated beings (siddha), (3) the mendicant leaders (ācārya), (4) the mendicant teachers (upādhyāya), and (5) all the mendicants (sādhu) (Donaldson 2017; Jaini 2001/1979, 162-63). ${ }^{35}$ Other acts of devotion include hymns of praise (stava) to the Jinas or the canon that transmits their teachings.

The preparatory restraints (mūla-guna) include eight restrictions regarding diet, namely refraining from eating meat, alcohol, honey, and five fruits in the fig family (ŚĀ 57-59). Although refraining from meat is an obvious restraint of ahims $\bar{a}$, the other food prohibitions are related to preventing harm to one-sensed nigodas considered prevalent in fermented, sweet, or seed-filled plants (GJK 186-91; Jaini 2001/1979, 166-68; see chapters 2 and 6). It is noteworthy that these preparatory restraints of the first pratima are not a result of taking the five vows, but are prerequisite to the vows. In fact, Robert Williams states that for the Digambaras, the müla-gunas are "a category of interdictions which must be respected if even the first stage on the ladder of the pratimās is to be attained" (1963, 50; see also Kirde 2011, 9-10). ${ }^{36}$

Pratimā 2: The Vows (Vrata). One who has appreciated the value of the fundamental devotions and preparatory restraints is ready for the next step in the 
pratimā path, called vrata-pratimā, or "the stage of taking the vows." There are twelve lay vows (śrāvaka-vrata), consisting of five minor vows (anu-vrata) and seven supplementary vows (see below). Each of the five minor vows represents a different restraint, to which we now turn.

First Minor Vow: Nonviolence (ahimsā) - The goal of nonviolence is rooted in two distinct, but overlapping, motivations. The first motivation, described above, is the recognition that all living beings are vulnerable to suffering and death, in accordance with which one should minimize all actions that could harm them. The second motivation is to restrain passions that inform the harmful activities of body, speech, and mind, and attract and bind karma (TS ${ }^{\text {Sv }} 6.5-7 ;^{37}$ Wiley 2006a, 438). In this latter understanding, violence "refers primarily to injuring oneselfto behavior which inhibits the soul's ability to attain mokșa" (Jaini 2001/1979, 167). Jaini explains that "the killing of animals, for example, is reprehensible not only for the suffering produced in the victims, but even more so because it involves intense passions on the part of the killer, passions which bind him [sic] more firmly in the grip of samsāra” (167).

Because the minor vow of ahimsā is partial, it permits laypeople to commit some harms to beings with fewer senses in the activities of their daily lives (Jaini 2001/1979, 241-43). Williams explains how mendicants must avoid sūkșmahims $\bar{a}$, or "subtle violence," toward all life-forms, including one-sensed beings, while laypeople endeavor to avoid sthüla-himssā, or "gross violence," toward beings with two or more senses (1963, 65-66; see also Balbir 2015, 91-92). This results in a functional hierarchy for those beings that mendicants must not harm (one- through five-sensed beings) and those that a layperson must avoid injuring (two- through five-sensed beings). Violating a being with more senses results in greater karma to the one causing injury.

Second Minor Vow: Truthfulness (satya)-The vow of truthfulness, which laity observe partially and mendicants fully, requires great care with the speech-related activities that might have destructive consequences. On one hand, this refers to utterances that are informed by the passions and, thus, injurious to the self that produces them. On the other, it also refers to the effects of speech acts that might be injurious to other living beings (Williams 1963, 71-78). In line with this, the vow of truthfulness prohibits speaking falsely; wrongly accusing another; insulting someone; causing embarrassment; encouraging another to perform injurious actions; wrong instruction; telling secrets; and so on. It is important to note that the considerations of the effects of actions that fall under this vow do not relate only to lying and deceit, but also to truthful utterances. Accordingly, the vow forbids speaking any truth that might lead to the destruction of embodied life-forms (77-78; Jaini 2001/1979, 174; SSi 7.14\$689; YŚ 2.61). Jaini explains, for example, that a layperson may mislead a hunter who asks where a deer went in order to prevent harm, resulting in only a minimal intake of karma, while a mendicant's complete vow necessitates silence (174; see also Dundas 2002, 160). Nalini Balbir affirms that 
"lay Jains can knowingly utter a falsehood if this stops a greater wrong" (n.d.). The vow of truthfulness also involves positively directing speech toward worthwhile pursuits that serve self and others (Williams 1963, 77).

Third Minor Vow: Nonstealing (asteya) - Nonstealing involves a restraint against stealing (steya) or taking what is not given (adatta-ädāna). For mendicants, the vow refers primarily to alms and mendicant equipment (Balbir n.d.), whereas for laity, it relates to everything that has not been either inherited or obtained through legitimate means (Jaini 2001/1979, 175). In practice, this can refer to taking something belonging to another person; receiving stolen goods; using deceptive measurements; or cheating others with counterfeit goods, which also overlaps the previous vow of truthfulness. Many of these restrictions clearly apply to business transactions. Stealing is also highlighted as an expression of violence, since it robs people of possessions that are their source of consolation and, thus, "takes away" their lives (Williams 1963, 78-84).

Fourth Minor Vow: Sexual Restraint (brahmacarya)-Jainism recognizes three sexes, namely male, female, and "third sex," as well as three parallel sexual feelings or desires (SSi 2.52; TS ${ }^{\text {Dig }} 8.9 ;^{38}$ see chapter 5 ). While sexual restraint for mendicants means eschewing all sexual desires and activities, which represent damaging passions and attachments (Jaini 2001/1979, 176-77), laypeople are to content themselves in monogamous spousal relations with moderate sexual activity. Refraining from sexual relations for specific periods of time and for pleasure is seen as virtuous behavior. We will explore the topic of sexual restraint in more detail in chapter 5 in relation to reproductive birth control.

Fifth Minor Vow: Nonpossession (aparigraha)-Nonpossession is a restraint with two distinct aspects: forgoing attachment to internal and external possessions, and forgoing the accumulation of possessions (Balbir n.d.). Internal (abhyantara) possessions include attachments to beliefs, emotions, sexual urges, fears, and desires; external (bahya) possessions include attachments to assets such as land, homes, money, servants, and furniture (Jaini 2001/1979, 177; Williams 1963, 93-94). Being attached to such possessions can fuel passions that may injure self and others through the actions of body, speech, and mind (Williams 1963, 99). Nonpossession also includes forgoing the accumulation of possessions. While, for mendicants, who observe the vow fully, this means walking away from all social and material bonds (see below), laypeople, who observe the vow partially, fulfill it by setting limits to material, psychological, and relational possessions.

The Seven Supplementary Vows - Lay Jains can strengthen their five minor vows with seven additional supporting restraints (called guna-vrata and śikșā-vrata). Laypeople may commit to these for the rest of their life, during holiday periods, or not at all.

Three guna-vratas support the minor vows by placing additional limits on activity and contact with life-forms and objects through various restraints. The first supplementary vow (dig-vrata) addresses limiting the area in which one walks or travels 
in order to minimize harm (YŚ 3.2-3). A layperson can geographically demarcate the boundaries of movement by referencing specific locations, or commit to restrict movement to a certain radius. The second (bhoga-upabhoga-parimāna-vrata) requires refraining from pleasures or enjoyments that increase attachments and may result in harm. Hemacandra describes a variation of this vow as placing limits on items used once (bhoga), such as food or a decorative garland, or those used repeatedly (upabhoga) for pleasure, such as a lover, house, bed, or vehicle (YŚ 3.47). This vow includes the restriction of eating plants that contain infinite numbers of nigodas (ananta-kāya) and eating at night (rätri-bhojana), as well as drinking only filtered water. The restrictions of performing various occupations, which will be discussed in more detail below, likewise fall under this vow. The third supplementary vow (anartha-danda-vrata) requires one to avoid purposeless activities such as listening to stories that instigate violence, dwelling on dark thoughts, digging the earth or cutting trees, gambling, or providing a means of destruction for others (Jaini 2001/1979, 178-80; Williams 1963, 99-131).

Four śikșa-vratas support the minor vows by introducing certain commitments that are to be observed on a regular basis, be it weekly, daily, monthly, and so on. These include (1) deśa-avakäśika-vrata, by which a layperson takes on an even more severe temporary restriction of travel than established with the dig-vrata, such as staying in a room, or limits communication, such as not speaking by phone or email, for a short term; (2) sāmāyika-vrata, by which one commits to regularly performing the meditative practice of equanimity (sāmāyika) for short periods; (3) undertaking a fast from eating and drinking, as well as refraining from performing household-related activities for a set period of time (poṣadha-upavāsa-vrata); (4) providing support to mendicants (dāna-vrata), such as preparing appropriate foods, as well as learning the acceptable modes of interaction and to recognize worthy recipients (Jaini 2001/1979, 180-81; Williams 1963, 131-72). Beyond these seven supplementary vows, lay Jains have the opportunity, though not the requirement, to take another supplementary vow of voluntary death toward the end of life, known as sallekhanā (also Śv. saṃthāra; detailed in chapter 7).

Pratimās 3-11. The remaining nine steps of the pratimā ladder require increased rigor in observing each of the twelve vows previously taken. An individual may or may not take these steps, demonstrating the wide range of advancement possible in this fifth guna-sthāna. Taking all nine of these remaining steps advances an individual to a state just short of the mendicant vows, which can be taken in the sixth guna-sthāna. These steps include (step 3) thrice-daily meditation (sāmāyika) akin to a mendicant's minimum requirement (sāmāyika-pratimā); ${ }^{39}$ (step 4) fasting (poṣadha) from food and drink as well as refraining from social and business activities on four auspicious lunar days each month (poșadha-pratimā); (step 5) giving up (tyāga) unboiled water, ${ }^{40}$ green leaves, shoots, raw seeds and fruit, as well as root vegetables, and other foods that mendicants avoid (sacitta-tyāga-pratimā) (in 


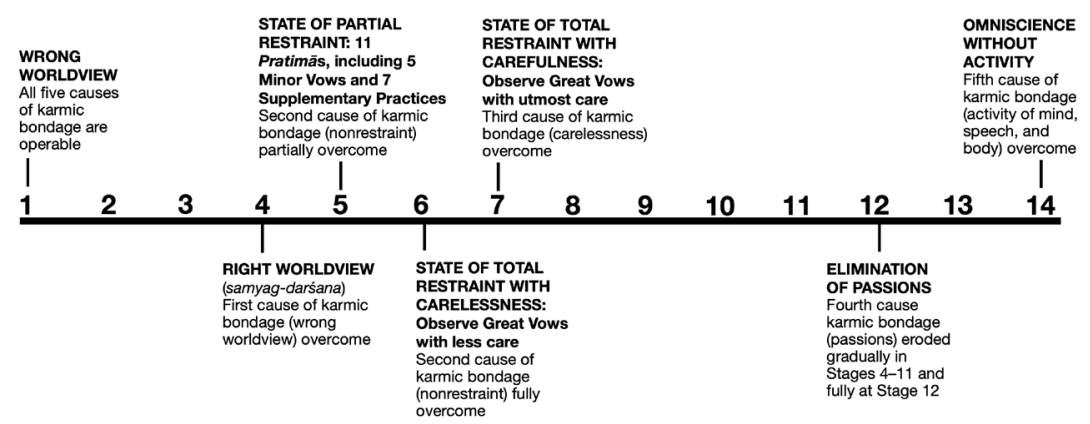

FIGURE 4. A diagram of the guna-sthānas, noting the particular causes of karmic bondage overcome at the respective stages. Credit: B. Donaldson.

addition to already eschewing meat); ${ }^{41}$ (steps 6 and 7) increasing the vow of sexual restraint, including engaging in sex only at night (rātri-bhakta-pratimā) or possibly advancing to absolute abstinence (brahmacarya-pratimā); (step 8) withdrawal from all personal harmful activities, including abandoning one's occupation, though one's employees or agents may still engage in such efforts (ärambha-tyāgapratimā); (step 9) releasing ties to possessions related to the lay life, including employees or agents, so that only one's family continues business activities, and so on (parigraha-tyāga-pratimā); and (steps 10 and 11) preparing for mendicant renunciation by total disengagement from household activities and, eventually, giving up all food and shelter prepared specially for oneself (anumati-tyāga-pratimā, uddișta-tyāga-pratimā). At the eleventh stage, one is considered "about to be a mendicant" (śramaṇa-bhūta) in the Śvetāmbara tradition. The layperson who has attained it emulates the mendicant lifestyle by carrying mendicant equipment, and possibly wearing mendicant clothes and shaving the head. The Digambara tradition divides this final step into two stages, that of a "junior/minor" (kșullaka), who dons three pieces of clothing, and that of an ailaka, who wears only a single piece of clothing (Jaini 2001/1979, 182-84; Petit 2015, 106-8; Williams 1963, 175-81). One can get a sense of where the vows and pratimās fit within the larger ladder of karmic removal in figure 4 (noting where each of the five causes of bondage is overcome).

Jaini claims that historically these pratimās were intended to be practiced "for a period of months equal to the 'step number' of that pratima" - that is, one month for the fundamentals, two months for the vratas, and so on, requiring five-and-a-half years of progress toward becoming mendicant-like (2001/1979, 185). "Thereafter," says Jaini, "the aspirant would usually (but not necessarily) decide to take the vows permanently," as a mendicant in the sixth guna-sthāna, though this timeline is no longer observed (185).

One who moves through all the pratimās succeeds in partially overcoming the second cause of bondage of nonrestraint (avirati), and is prepared for the next step of accepting the great vows. 


\section{Rungs 6 and 7: Mendicant Restraints: From Careless \\ to Careful Practice of the Great Vows}

The sixth guna-sthāna, called "total restraint" (sarva-virata), signifies fully overcoming the second cause of bondage, that of nonrestraint (avirati) (AA 5; GJK 32). The pratyākhyāna-āvarana passions, or "obstructors of complete renunciation," that prevented total restraint in the previous stage are now overcome, enabling one to take the five great vows (mahā-vrata) as part of a formal initiation (dikssa) or renunciation (pravrajyā) ceremony for entry into mendicant life. This ritual publicly signifies the rebirth of an aspiring monk or nun who has left their name, family, social status, occupation, possessions, and clothing (Jaini 2001/1979, 243-46).

In spite of one's having attained this significant milestone, Jaini points out that very subtle passions still operate at this level, known as "smoldering passions" (samjvalana, lit. "fuel") (120). While these passions "are not sufficiently strong to prevent one from entering the mendicant's path," he says, "they induce an insidious state of apathy or inertia (pramäda), a lack of drive with regard to the the actual purifactory practices entailed by that path" (120). Glasenapp refers to these as "flaming-up passions" that stoke the third cause of karmic bondage, carelessness (pramāda) ${ }^{42}$ which undermines the newly achieved self-control (1942/1915, 82). ${ }^{43}$ Wiley states that these smoldering passions "cause lapses or carelessness in observing the mendicant vows and an unconscious attachment to life" $(2009,121)$. Consequently, the sixth guna-sthana is also known as the stage of "restraint with carelessness" (pramatta-virata).

In the seventh guna-sthāna, however, the third cause of bondage, carelessness, is overcome so that a mendicant can practice the great vows carefully. Hence, the seventh rung is called "restraint without carelessness" (apramatta-virata). Tatia describes this rung as "self-control with freedom from spiritual inertia (apramattasamyata)" (1951, 277; see also GJK 45), while Glasenapp calls it "complete selfcontrol without negligence" $(1942 / 1915,83)$.

As in previous stages, the movement between the sixth and seventh rungs is not linear. One may briefly suppress the "smoldering" passions that cause carelessness, and experience moments of careful practice, then slide back toward carelessness, repeating this advancement and regression many times (Glasenapp $1942 / 1915,82$ ). To aid in this transition as well as propel one to the further stages on the path of karmic removal, mendicants undertake several supporting practices, which will be discussed in the next section.

Mendicant Supporting Practices. In order to strengthen one's adherence to the five vows by continuing to reduce the frequency, duration, and space of one's actions, and thereby gradually stop the accrual of new karma (samvara), mendicants assume three additional restraints and five additional rules of conduct, known as the "eight matrices of doctrine" (așta-pravacana-mātrka) (Jaini 2001/1979, 247; see 
also GJK 472). These eight supporting practices prepare one, as Jaini states, "for the advanced meditational states through which karmic matter is finally eliminated from the soul" $(2001 / 1979,247)$. The three restraints, or guptis, require one to further limit the activities of body (kāya-gupti), speech (vāg-gupti), and mind (mano-gupti), for instance by quieting the mind from thoughts and practicing silence and stillness (TS 9.4). The five supporting rules, or samitis, include using (1) extreme care in walking, to avoid injuring small living beings (ìryā-samiti); (2) care in speaking infrequently and only when needed, to utter only truth or remain silent (bhāṣa-samiti); (3) care in accepting alms by making certain the food is appropriate, and eating it without excess pleasure (eșan̄a-samiti); (4) care in picking up and setting down any object, such as a water pot or alms bowl, to avoid harming living beings (ādāna-nikșepana-samiti); and (5) care in executing excretory functions, by choosing a proper place, so as not to harm other beings (utsarga-samiti) (TS 9.5; Jaini 2001/1979, 247-48).

Mendicants also undertake twelve mental disciplines, called anuprekṣās (Dig.) or bhāvanās (Śv.), in which they reflect on impermanence (anitya), helplessness in the face of death (aśaraña), the cycle of rebirth (samsāra), the existential solitude of every individual's karmic path (ekatva), the distinction of body and jiva (anyatva), the karmic impurities that characterize a visually attractive body (aśuci), the reality of karmic inflow (āsrava), how to stop the inflow (samvara), how to erode existing karma (nirjarā), the nature of the cosmos (loka), the rarity of human birth alongside the greater rarity of true insight (bodhi-durlabha), and the absolute truth of the (Jina's) teachings (dharma-svākhyātatva) (TS 9.7; Jaini 2001/1979, 248; Sogani 2016, 155-58). ${ }^{44}$ These twelve reflections are accompanied by cultivating the increasing perfection of ten moral virtues (daśa-dharma): patience (kṣamā), modesty (mārdava), honesty (ärjava), purity (śauca), truthfulness (satya), restraint (samyama), austerity (tapas), renunciation (tyāga), nonattachment (ākiñcanya), and sexual control (brahmacarya) (TS 9.6; Jaini 2001/1979, 248).

Additionally, mendicants assume six daily obligatory practices (āvaśyaka) that support discipline and provide a means of karmic expiation or austerities. ${ }^{45}$ Some of these practices parallel those in the layperson pratimās of the fifth guna-sthāna, and they are themselves also recommended for laity. The six practices include (1) attaining a state of mental equanimity (sāmāyika), (2) venerating the twentyfour Jinas (caturvimśati-stava), (3) honoring the mendicants (guru-vandana), (4) confessing one's daily harms (pratikramana), (5) ascetic posture indicating the abandonment of the body (kāya-utsarga), and (6) fasting from certain foods or activities for a determined time (pratyākhyāna) (Balbir 1993; Williams 1963, 185).

By practicing these restraints and rules of conduct, mental reflections, moral virtues, and daily disciplines, mendicants prepare themselves to bear common "hardships" (parișaha) of mendicant life, which will help them stay on the spiritual path and remove karma (TS 9.8). The Tattvārtha-sütra, for example, names twenty-two such hardships, ranging from hunger, thirst, cold, heat, and insect 
bites to injury and illness, among others (TS 9.9; see also US 2). These hardships gradually decrease as one progresses in the guna-sthānas, as does one's reaction to them. ${ }^{46}$

Furthermore, in order to remove the karma that has already been accumulated, mendicants perform a wide range of voluntary ascetic practices (tapas). These are divided into twelve types, six external and six internal (US 30). The six external types are (1) fasting (anaśana); (2) reduced quantity of food (avamaudarya); (3) limitations relating to the gathering of alms (vrtti-parisamkhyāna); (4) refusing tasty food (rasa-parityāga); (5) staying in isolated places (vivikta-śayyāsana); and (6) bodily mortifications (kāya-kleśa) (TS 9.19). The six internal types are (1) expiation of transgressions (prāyaścitta); (2) reverence (vinaya); (3) service to the teacher and other mendicants (vaiyāvrttya); (4) study (svādhyāya); (5) renunciation of attachments (vyutsarga); and (6) meditation/concentration (dhyāna) (TS 9.20).

Finally, mendicants may also take the vow of sallekhanā, or the voluntary fast unto death, toward the end of their life (as detailed in chapter 7 ).

The sixth and seventh guna-sthānas demonstrate that mendicants take the vows with varying degrees of carelessness and carefulness, or in Tatia's translation, "spiritual inertia" and "spiritual vigor" $(1951,275)$. He states that the jivva "fluctuates between the state of spiritual vigor and the state of spiritual inertia a hundred times before it reaches the state of steady progress" (275). Once a mendicant begins to increasingly overcome carelessness, the ability to rigorously practice meditation, particularly pure concentration (śukla-dhyāna), propels one to the next rung on the guna-sthāna ladder (Jaini 2001/1979, 253).

\section{Rungs 8-12: Stages of Meditation to Suppress or Eliminate the Remaining Passions}

Having overcome three of the five causes of bondage at this point, individuals who reach the eighth guna-sthāna-called apürva-karana, or "unprecedented activity"-will proceed to diminish the remaining passions and karmas either through a path of suppression (upaśama-śreni), which is the less effective route, or a path of elimination (kșapana-śreni/kșapaka-śrenii), which is the more effective route.

The eighth rung is considered "unprecendented" because one can, in a relatively short period that one stays in the rung (one antar-muhürta, or less than forty-eight minutes), begin to reduce the duration and intensity of previously bound karmas, as well as new karmas, more effectively than at any other point in their history (Tatia 1951, 271-72, 277). In this rung, the meditative practices of pure concentration (śukla-dhyāna) enable the mendicant to confront the remaining "smoldering" passions (samjvalana-kașāya), as well as a lingering group of subsidiary passions, called no-kașāya, including mundane emotions such as laughter, pleasure and displeasure in sense activity, sorrow, fear, disgust, and sexual feelings/ desires (Jaini 2001/1979, 118-21; Wiley 2009, 158). Jaini explains: "The degree to 
which these no-kașāyas are manifest decreases with spiritual advancement; hence a monk is likely to laugh or weep or feel revulsion much less than ordinary people do, while for the kevalin [rungs 13 and 14] there are no such activities or feelings whatsoever" (120).

The emotional passions of no-kașaya are "rendered inoperative" in the eighth as well as the ninth rung, called anivrtti-karana, or "no return process" (Jaini 2001/1979, 257). Nearly all the smoldering passions are overcome in the tenth rung, called sūkṣma-sāmparāya, because only the most subtle (sūkșma) passion of greed (lobha) is still operative (Glasenapp 1942/1915, 87). Tatia states that this form of greed "can be interpreted as the subconscious attachment to the body even in the souls which have achieved great spiritual advancement" (1951, 278).

What happens at the eleventh guna-sthāna-called upaśänta-moha, or "pacified delusion"-depends on whether one has taken the less effective path to suppress (upaśama-śrenii) or the more effective path to eliminate (kșapana-śreni/kșapakaśreni) the remaining passions and karmas through the previous three rungs of meditation. Suppressing the karmas and passion is effective enough to enable an individual to reach the eleventh stage for a short delusion-free period, which is immediately followed by a fall to a lower rung (Glasenapp 1942/1915, 88). If one has taken the path to elimination, one "will pass over the eleventh gunasthāna altogether" (Jaini 2001/1979, 257), and reach the twelfth guna-sthāna-called kșinamoha, or "destroyed delusion" - in which all of the subtle smoldering passions are totally eliminated, meaning that all the deluding (mohaniya) karmas are destroyed.

With this achievement, the fourth cause of karmic bondage-the passions, which have been operative for the entirety of embodied existence across innumerable rebirths-are finally overcome, and one gains a state of perfect conduct (yathākhyāta-cāritra) (Jaini 2001/1979, 258). One who reaches the twelfth rung of perfect conduct and obliterates passions will not fall below this stage again and guarantees the inevitable push toward liberation.

\section{Rungs 13 and 14: Attaining Embodied Omniscience and Liberated Omniscience}

As the last passions are overcome, all the remaining ghātiya karmas (karmas destructive of the jiva's qualities; see chapter 2) are eliminated. The jivva's qualities of perception, knowledge, energy, and bliss are fully realized in the thirteenth guna-sthāna. One who reaches this stage is a "supreme" (parama) self (AA 1, 7-8, trans. Petit) known as arhat or kevalin, the latter referring to the possession of omniscient, unobstructed cognition called kevala-jñāna (see chapter 2). ${ }^{47}$ At this stage, the only remaining cause of karmic bondage is activity ( $y \circ g a$ ) of body, speech, and mind, which is why the practitioner who attains it is called sayoga-kevalin, or "omniscient with vibratory activity" (GJK 64, trans. Jaini). The only karmas still active are the nondestructive aghātiya a karmas related to body, longevity, status, and feeling (see chapter 2). As Glasenapp summarizes, "the Sayogi-kevalì [kevalin 
with activity] knows everything, sees everything, is capable of everything, yet he has a body and a certain activity which is conditioned by matter, and a number of [nondestructive] Karmas obtained earlier are produced in him" (1999/1925, 225). It should be pointed out that if one attained particular name-determining karmas associated with teaching in a previous lifetime, the Kevalin will become a Jina, a propagator of Jain teachings, in this rung (TS $\left.{ }^{\text {Dig }} 6.23^{48}\right)$.

An individual remains in the thirteenth rung until the time of death. No karma is generated during this time. Digambara sources, in fact, say that a kevalin does not even eat or drink at this point, though Śvetāmbara sources dispute this, saying that food and drink are ingested as usual by the mendicant, just without karmic accrual (Jaini 2001/1979, 268). In the last stages of embodied life, one undertakes the final forms of meditation related to subtle movement (sükșmakriyā-anivartin), by which all gross bodily activities as well as gross and subtle mental and verbal activities cease, and absolute nonmotion (vyuparatakriyā-anivartin) (270), by which even subtle bodily activities are brought to a stop (Jaini 2001/1979, 269-70; Tatia 1951, 279-80).

This latter state of nonmotion is the fourteenth guna-sthāna, in which the practitioner is called ayoga-kevalin, or "omniscient without vibratory activity" (GJK 65, trans. Jaini). The jivva in this state is free of the last cause of karmic bondage of activities of body, speech, and mind. This immobile state is very brief, ${ }^{49}$ and at the instant of death, longevity-determining karma expires and the jivva follows a natural movement upwards to the highest point in the cosmos, where it will remain as a disembodied liberated being (siddha) (see chapter 2).

\section{VALUE OF THE GUNA-STHĀNAS FOR BIOETHICAL REFLECTIONS}

It is important to remember that the guna-sthanna ladder is only a theoretical model; it is unclear to what degree modern lay Jains follow the technical details of these stages, especially when they cannot surpass the fifth level, nor can mendicants living in our time period surpass the sixth (Dundas 2002, 151-52). However, the framework is worth considering in a Jain approach to bioethics because all living beings are linked within it, including non-Jains as well as Jain laypeople and mendicants, in a continuum of right worldview, knowledge, and conduct (Petit $2015,97)$. Although the state of liberation exceeds detailed description, it promises the possible culmination of immense efforts across lifetimes in which all beings can participate.

The logic of the guna-sthannas in the overall framework of Jain ethics becomes clearer as we look backwards. The five causes of karmic bondage-wrong worldview; nonrestraint; carelessness; passions; and activities of body, speech, and mind-are overcome as one progresses along the ladder of karmic removal. The ordering of these five causes is also significant. The fifth cause of activity, 
for instance, is the last to be removed because activity itself is the most foundational cause of bondage for any living being (as discussed in chapter 2). Activities of body, speech, and mind condition passions, the next most persistent cause of bondage, of which the most subtle forms are operational until the twelfth rung. Activity and passions underlie carelessness, the third cause of bondage; these three together underlie nonrestraint, the second cause of bondage; and these four together underlie wrong worldview, the first cause of bondage. Tatia explains that "of these five [causes], the succeeding ones necessarily exist on the existence of the preceding ones, although it is not necessary that the preceding ones should exist on the existence of the succeeding ones" $(1951,147)$. Hence, the ladder of karmic removal is, in effect, the stripping away of symptoms generated by the subsequent cause of bondage, until even the primary cause of activity itself is neutralized.

However, lay Jains, who live and work in occupational and social settings where bioethical calculations are part of daily life, remain engaged in activity, as well as passions, carelessness, nonrestraint, and perhaps even wrong worldview if they have not yet reached the fourth rung of the ladder. Even a very disciplined layperson, who takes the minor vows and progresses through the eleven pratimās, can only attain the fifth guna-sthāna by virtue of having partially overcome the bondage of nonrestraint. Additionally, as is clear by the description of the mendicant path above, even mendicants who have taken the great vows may still be overcome by causes of bondage at the higher rungs.

Hence, the guna-sthānas offer a perplexing framework. On one hand, Jain ethics is rooted in extremely rigorous disciplines directed at the effects of body, speech, and mind. On the other hand, these are not always practiced in a uniform way. A single person will advance and regress continuously. The overall aim is to persistently strive to overcome the causes of karmic bondage unique to one's path of existence, to cultivate right worldview, right knowledge, and increasingly right conduct. Jain ethics will not always look the same, but the guna-sthānas provide a collection of concepts illuminating the highest ideals, strategies of practice, and the damaging reality of careless, passion-driven activities.

\section{VICES AND THE VIOLATIONS OF THE MINOR VOWS}

The guna-sthannas make clear that harm is inescapable for a layperson entangled in responsibilities of family, community, and work. As Jaini puts it, these efforts to systematize lay conduct "outlined a path of nonviolence that would allow a lay adherent to conduct his [sic] daily life with human dignity while permitting him to cope with the unavoidable reality of the world in which violence is all-pervasive" $(2004,60)$. The fact of harming, however, does not lead to apathy or an "anything goes" attitude toward injury. On the contrary, texts reflect efforts to circumscribe the limits of harm, and to distinguish violations of vows that fall outside those limits, as well as vices that fuel harmful actions. Since bioethical issues largely 
concern laity and since a substantive portion of part 2 of this book will analyze contemporary Jain medical professionals, it is important to explore these vices and violations of lay vows more closely, as well as specifically discuss the occupational restrictions for laity.

The Tattvārtha-sūtra lists five violations (aticāra) for each of the lay vows. Five violations of the minor vow of nonviolence (ahims $\bar{a})$ include "Tethering, beating, piercing the skin, overloading, and withholding food and drink" (TS ${ }^{\text {Dig }} 7.25^{50}$ ). Five violations of the minor vow of truthfulness (satya) include providing wrong instruction, divulging secrets, forging documents, misusing entrusted funds, or sharing confidential thoughts of others (TS ${ }^{\text {Dig }} 7.26^{51}$ ). Five violations of the minor vow of nonstealing (asteya) include "Abetting theft, dealing in stolen goods, transgressing the limits of a hostile country, using false weights and measures, and dealing in counterfeit goods" (TS ${ }^{\text {Dig }} 7.27^{52}$ ). Five violations of the minor vow of sexual restraint (brahmacarya) include "Matchmaking, intercourse with a woman temporarily taken to wife, intercourse with an unmarried woman, unnatural sexual practices, and excessive sexual passion" (TS ${ }^{\mathrm{Dig}} 7.28^{53}$ ). Five violations of the minor vow of nonpossession (aparigraha) include "The failure to keep within the set limits of cultivable land and houses, silver and gold, livestock and grain, male and female servants, and of base metals, clothes/furniture" (TS $\left.{ }^{\text {Dig }} 7.29^{54}\right)$. The text goes on to list five violations for each of the seven supplementary vows, as well as the vow of sallekhana (TS 7.25-32), lists that are also included in the commentaries on this text. ${ }^{55}$ Those violations that are particularly relevant for bioethical issues will be explored further in part 2.

Specific vices (vyasana) and sub-vices (sodara) unique to laypeople are also cited in medieval manuals of lay conduct written by authors of both main Jain sects. A list of seven vices is found in multiple Digambara texts, suggesting a common source. These include gambling, consuming alcohol, eating meat, engaging with prostitutes, hunting, stealing, and adultery (Williams 1963, 247). The Śrāvaka-àcāra of the Digambara teacher Amigati (eleventh century CE) considers these seven acts vices because they engender particularly strong passions or lead to other vices in the laity; eating meat, for instance, can encourage drunkenness, making religious progress impossible (248).

Śvetāmbara texts do not display the same uniformity regarding the vices, but many similar warnings are found therein; Hemacandra's Yoga-śāstra, for instance, explains the potent power of alcohol: "Judgment, (self-)control, knowledge, truth(fulness), purity [of conduct and] compassion, all are extinguished by liquor, just as a haystack is [extinguished] by a spark of fire" (YŚ 3.16, trans. Qvarnström). These vices reflect the social setting of Jain laypeople likely engaging in activities among non-Jains. In fact, the last two vices named by Amigati, stealing and adultery, were also punishable by civic law, making one susceptible not only to immense karmic bondage and personal torment, but also to legal punishments (Williams 1963, 249-50). 


\section{Forbidden Occupations for Householders}

Jain texts also specify occupations that are forbidden to lay Jains. The canonical Upāsaka-daśāh (Pkt. Uvāsaga-dasāo) ${ }^{56}$ lists fifteen forbidden occupations that are also cited by at least one Digambara author. ${ }^{57}$ Several of these modes of employment (marked with an asterisk below) have direct bearing on medical professions and bioethical contexts, including pharmaceutical production, cultivating medicinal plants, animal research, and beyond, which we reference in the following chapters. Forbidden jobs include earning a livelihood from

(1.) making, buying, or selling charcoal or smelting other metals that kill multiple types of living beings*

(2) destroying plants, such as cutting trees, plants, or grinding grains or pulses*

(3) construction or sale of carts hauled by animals, which binds the animals and crushes living beings on the path

(4) transporting goods by vehicles or animals*

(5) excavating soil for agricultural purposes, wells, or rock quarries, which disturbs mobile and immobile beings*

(6) trade in animal byproducts such as shells, ivory, yak tails, bones, pets, or goose down, which instigates industries of killing ${ }^{\star}$

(7) trade in chemicals or pigments used in poisons, dyes, or alcohol in which insects or minute living beings are destroyed in the cultivation or fermentation*

(8) trade in alcohol or forbidden foods such as meat, honey, butter, and other foods that torment animals or foment violent passions in those who ingest them*

(9) trade in men and animals, especially for profit, which restricts others' freedom and often involves hunger, thirst, beating, and being tied up ${ }^{*}$

(10) trade in weapons or tools that can kill plants, animals, and people, such as swords, guns, and farm implements*

(11) work in mills, such as crushing of sugarcane, seeds, or beans, which destroys plants and water-bodied beings

(12) work involving the mutilation of animals, such as castration, tail docking, nose piercing, or cutting of ears or other body parts

(13) burning to clear fields or for ritual purposes, which destroys many life-forms

(14) taking water from tanks, lakes, or ponds for irrigation or other purposes, which destroys aquatic lives

(15) breeding or rearing children for prostitution or as eunuchs, or breeding animals for use* (Williams 1963, 117-21)

Exceptions have been made to the above guidelines, especially in Digambara texts, for a member of a warrior caste required to bear arms or a member of an agricultural caste required to till the soil. Phyllis Granoff refers to these exceptions 
as "temporary lapses" (chindikāa —a term seemingly present only in medieval literature - in which a Jain could knowingly violate a precept to accommodate significant outside pressures (2000, 139-40). If one could maintain right worldview during these "lapses," the action would not be viewed as a karmic violation, nor would it prevent the ability to continue on a devout path.

Śvetāmbara and Digambara texts on lay conduct ${ }^{58}$ offer short lists of permissible occupations (upāya) for laity. Digambara sources describe the merchant trade, clerical occupations, agriculture, artisanal crafts, and caste-related military occupations. Śvetāmbara texts forgo military occupations, but agree with the remaining list, adding practice of medicine, service to a political ruler, and begging (Williams 1963, 122).

\section{JAIN FOUNDATIONAL PRINCIPLES FOR ETHICS}

Jain philosophy and textual history demonstrate a central and unparalleled concern with nonviolence to one- through five-sensed beings. However, neither the single concept of nonviolence nor its relation to the other four vows offers a sufficient summary of Jain ethics. Rather, the ethical outlook of Jainism includes a complex framework of disciplines that contains various principles, all of which are significant when considering a Jain engagement with contemporary bioethics. We have identified three key principles.

First, since its earliest texts, Jainism is characterized by a special attention to violence and nonviolence. The ancient concept of parigraha, for instance, identified attachments to objects, pleasures, and social relationships as leading to physical actions that cause inevitable violence, or ärambha. Additionally, early texts describe a triple harm in body, speech, and mind, committed in a triple manner of doing, causing others to do, or approving of what others do. Nonviolence, as the most central of the five main vows now synonymous with contemporary Jainism, is an evolving expression of these early concepts.

Second, Jainism offers distinct paths for non-Jains, Jain laity, and mendicants, and these paths are marked by progression and regression in the guna-sthanas. All one- through five-sensed living beings, as well as Jains and non-Jains, are said to exist along this ladder of karmic removal. As a social discipline, bioethics primarily applies to laity up to the fifth stage of the ladder. Consequently, the context of modern bioethics, when seen through a Jain philosophical lens, is subject to high degrees of karmic bondage and should not be confused with the highest guna-sthānas characterized by overcoming all karmic passions and, ultimately, activity itself.

Third, within the realm of lay ethics, there are numerous guidelines to help restrain the inevitable harms of one's professional, family, and social life. Although the highest stages of karmic removal are inaccessible to one who lives and works 
in the world, Jain ethics includes considerations and practices meant to decrease harm to one- through five-sensed beings, which could shape modern bioethical calculations, inform one's occupation, and demarcate lines of ethical compromise and ethical non-negotiables.

In summary, Jain ethical principles exist in a broad framework centered on nonviolence, but exceed any single concept. Jain ethics reveal an adaptive philosophy for an evolving community accounting for elements of action and inaction, intervention and withdrawal, compassion and isolation, and karmic injury and karmic benefit. While Jain ethics may be characterized by the goal of emulating the twenty-four Jinas, it must at the same time be understood as a gradual process of striving to overcome the causes of karmic bondage, namely wrong worldview, nonrestraint, carelessness, passions, and, ultimately, all activities of body, speech, and mind. This rich ethical framework also informs Jain attitudes toward medicine from antiquity to the present, to which we now turn. 